\title{
Binding of glycolytic enzymes in adductor muscle of Iceland scallop Chlamys islandica is altered by reproductive status
}

\author{
Katherina Brokordt ${ }^{1,2}$, Helga Guderley ${ }^{1, *}$ \\ ${ }^{1}$ Département de Biologie and Quebec-Océan (Le Groupe Interinstitutionnel de Recherches Océanographique du Québec), \\ Université Laval, Quebec City, Quebec G1K 7P4, Canada \\ ${ }^{2}$ Present address: Departamento de Ecología, Pontificia Universidad Católica de Chile, Alameda 340, Santiago, Chile
}

\begin{abstract}
During gonad growth and spawning by the Iceland scallop Chlamys islandica, muscle glycogen levels decrease in parallel with the activities of several glycolytic enzymes, including glycogen phosphorylase (GP), pyruvate kinase (PK) and octopine dehydrogenase (ODH), even though muscle protein concentrations remain unchanged. These parallel changes suggested that binding of glycolytic enzymes to glycogen influences their activities. Decreases in the amount of glycogen in the muscle would reduce the number of binding sites for these enzymes and decrease measurable activities or accelerate their degradation. We tested this hypothesis by evaluating the impact of reproductive status on the activity and intracellular distribution of GP, PK and ODH in adductor muscle of inactive Iceland scallops. Glycogen, but not protein, levels decreased markedly during gonad maturation and spawning. GP and ODH activities decreased in parallel with glycogen, while PK activity did not change. GP showed the highest binding both to glycogen (9 to 19.5\% of activity bound) and to the particulate fraction (37 to $53 \%$ ). As the units of GP bound per mg glycogen did not change with maturation and spawning, the total units of GP bound to glycogen decreased with maturation and spawning in females and males. For the enzymes measured, more activity was bound to the particulate fraction than to glycogen. The units of ODH bound to glycogen and to the particulate fraction decreased during maturation and spawning in females. Within a reproductive state and within a cellular fraction, the relative activities of the glycolytic enzymes (ODH/GP and PK/GP) were quite similar, suggesting conservation of the stoichiometry of glycolytic enzyme capacities in a given cellular fraction. Enzyme-binding to the particulate fraction of scallop adductor muscle shifts with long-term physiological change. Our results are compatible with the interpretation that the intracellular localization of enzymes influences their rates of synthesis and degradation.
\end{abstract}

KEY WORDS: Enzyme-binding · Glycogen · Glycogen particles · Glycolytic enzymes · Scallops · Reproduction · Reproductive cost · Chlamys islandica

\section{INTRODUCTION}

Reproduction can lead to marked mobilization of reserves from somatic tissues in support of gametogenesis and spawning. In scallops, mobilization of reserves from the adductor muscle is common (for a review see Barber \& Blake 1991). Whereas the extent of mobilization of somatic reserves varies according to food availability during gametogenesis and spawning and with life history strategy (single vs multiple spawning), glycogen from the scallop adductor muscle is the somatic reserve most frequently used during gonad growth and spawning (Brokordt \& Guderley in press). In contrast, muscle protein concentrations change far less. Adductor-muscle glycogen levels can be twice those of soluble proteins in the tropical scallop Euvola ziczac (Brokordt et al. 2000b), whereas in the Iceland scallop Chlamys islandica, glycogen levels are half 
those of soluble proteins (Brokordt et al. 2000a). The sparing of muscle proteins probably reflects their functional importance for muscle contraction and metabolism as well as the cost of their degradation and synthesis.

Although adductor-muscle proteins are spared during gametogenesis and spawning, marked changes in the muscle activities of glycolytic and mitochondrial enzymes occur during gonadal growth in Chlamys islandica and Euvola ziczac. In both species, enzyme levels in the adductor muscle are highest in immature individuals, drop during maturation, and fall further during spawning (Brokordt et al. 2000a,b). In E. ziczac, this cycle of enzyme activities was repeated during 2 successive reproductive cycles in 1 yr (Brokordt et al. 2000b). As muscle protein contents did not change over this period in C. islandica and changed little in $E$. ziczac, the decreases in enzyme activities do not reflect a general protein breakdown. On the other hand, changes in the activities of the glycolytic enzymes, glycogen phosphorylase (GP), octopine dehydrogenase $(\mathrm{ODH})$, pyruvate kinase $(\mathrm{PK})$ and phosphofructokinase (PFK), closely paralleled changes in muscle glycogen levels. A possible explanation of these parallel changes is that active enzymes may be preferentially bound to glycogen particles. Decreases in the concentration of muscle glycogen would reduce the availability of sites for enzyme-binding and either decrease their measurable activities or reduce the number of enzyme molecules by enhancing rates of degradation. Alternatively, a regulatory mechanism may adjust enzyme activities according to glycogen concentrations. Both mechanisms could explain why the changes in enzyme activity during gametogenesis and spawning are considerably greater than the changes in protein concentrations.

The binding of enzymes to subcellular structures has been suggested to act as a means of facilitating metabolic flux (Srere 1987). Glycolytic enzymes bind to glycogen and myofibrils (Choate et al. 1985, Birkel et al. 1986, Roberts \& Somero 1987). In particular, glycogen synthetase, glycogen phosphorylase and their regulatory enzymes are associated with glycogen particles. While the regulatory importance of changes in glycolytic enzyme-binding is controversial (Brooks \& Storey 1991), changes in protein localization, such as the exposure of actin to myosin-binding, clearly can play major roles in activation of metabolic flux (Hochachka \& Somero 2002). Interestingly, glycogen mobilization from the scallop adductor muscle is not only accompanied by decreases in the activities of muscle enzymes, but also by reduced recuperation from exhaustive exercise during valve closure and subsequent aerobic recovery (Brokordt et al. 2000a,b). Reduction in the numbers of an enzyme-glycogen complex that facilitates glycogen degradation could reduce flux through glycolysis, thereby slowing recuperation.

Our study is based upon the premise that the dramatic decreases in muscle glycogen concentration during gametogenesis and spawning by scallops may have other functional impacts than simply reducing fuel availability. We postulate that one of these impacts is a decrease in the binding of glycolytic enzymes to glycogen and that this change is linked to the decrease in enzyme activity observed during gametogenesis and spawning. Thus, we examined whether the mobilization of muscle glycogen during gonad development and spawning of Iceland scallop Chlamys islandica decreased the binding of the glycolytic enzymes GP, $\mathrm{ODH}$ and $\mathrm{PK}$ to glycogen particles. We also monitored their binding to the particulate fraction (presumably primarily myofibrils), as glycogen mobilization could increase the availability of glycolytic enzymes for binding to other subcellular fractions.

\section{MATERIALS AND METHODS}

Sampling of scallops and muscles. 20 adult scallops (shell height 79 to $81 \mathrm{~mm}$ ), 10 females and 10 males, were collected in the Mingan Islands $\left(50^{\circ} 14^{\prime} \mathrm{N}, 63^{\circ}\right.$ $36^{\prime} \mathrm{W}$ ) in the northern Gulf of St. Lawrence, eastern Canada, by SCUBA diving at $37 \mathrm{~m}$ in depth on 30 May, 20 July and 14 August 2000. For both females and males, these sampling dates corresponded to the period when the gonads were immature, completely mature and spawned, respectively (Brokordt et al. 2000a, Brokordt \& Guderley in press). The scallops were returned to a wet-laboratory at Havre St. Pierre and maintained in running seawater $\left(4\right.$ to $\left.6^{\circ} \mathrm{C}, 30 \mathrm{psu}\right)$ for at least $2 \mathrm{~d}$ without disturbance before tissue sampling and dissection. At each sampling period, one part of the phasic muscle was rapidly excised and quickly frozen ( 1 min) using a freeze-clamping press (Gagnon et al. 1998) that had been chilled in liquid nitrogen. We determined the shell height and muscle wet and dry mass (approximately $0.5 \mathrm{~g}$, oven-dried for $48 \mathrm{~h}$ at $70^{\circ} \mathrm{C}$ ). Muscle samples were transported in liquid nitrogen to Laval University and stored at $-70^{\circ} \mathrm{C}$ until determination of enzyme activities, glycogen and protein contents.

Preparation of glycogen particles and particulate fraction. Our isolation of glycogen particles was based on the approach of Birkel et al. (1986). We chose this approach rather than separation by centrifugation into soluble and insoluble fractions (Clarke et al. 1984) as it allowed virtually quantitative isolation of glycogen from the particulate fraction. Nonetheless, the dilution and disruption involved in any extraction technique 
may change the distribution of enzymes among subcellular structures.

Samples of phasic adductor muscle were homogenized on ice using a Polytron (Brinkman Instruments), in 7 vol. of $2 \mathrm{mM}$ HEPES (4-(2-hydroxiethyl)-piperazine-ethanesulfonate buffer, $\mathrm{pH}$ 7.0) containing $3 \mathrm{mM}$ EDTA- $\mathrm{Na}_{2}$ (ethylene dinitrilotetra-acetic acid). The low salt concentrations in this buffer should minimize ionic disruption of binding between enzymes and subcellular components. An aliquot of $0.2 \mathrm{ml}$ of the homogenate was diluted with $1 \mathrm{ml}$ buffer and kept for measurement of total enzyme activity and to control for the recovery of enzyme activity in the soluble and insoluble fractions (glycogen and particulate fractions). Two additional aliquots of $0.2 \mathrm{ml}$ were kept to evaluate total glycogen and protein contents. The rest of the homogenate was centrifuged at $10000 \times g$ at $4^{\circ} \mathrm{C}$ for $20 \mathrm{~min}$ to precipitate the particulate fraction. This pellet was resuspended in the homogenization buffer and kept to evaluate enzyme-binding to the particulate fraction. We also kept an aliquot of $0.2 \mathrm{ml}$ to evaluate whether glycogen was present in this pellet. The glycogen particles were sedimented by centrifugation of the supernatant at $48000 \times g$ at $4^{\circ} \mathrm{C}$ for $70 \mathrm{~min}$. The resulting glycogen pellet was resuspended in the homogenization buffer and kept to evaluate the amount of enzyme bound to glycogen and the glycogen content. The supernatant was used to evaluate the amount of soluble enzyme. Preliminary experiments established that these extraction and centrifugation conditions were optimal for the separation of glycogen from the particulate fraction. Nonetheless, we followed glycogen levels throughout the different fractions in case physiological changes during the reproductive cycle led to shifts in glycogen fractionation. While our isolation of glycogen does not distinguish its different storage forms, it provides an indication of the enzymes bound to total muscle glycogen.

Glycogen was determined by enzymatic hydrolysis with amyloglucosidase as described by Keppler \& Decker (1974). Muscle protein concentration was determined using the bicinchoninic acid method of Smith et al. (1985) with bovine serum albumin as the standard.

Enzyme assays. We determined the activities of the glycolytic enzymes, GP, PK and ODH as described in Brokordt et al. (2000a). The activity of each enzyme was measured in the muscle of females and males at different reproductive stages, in the initial homogenate (total activity, control) and in 3 cellular fractions: (1) enzyme bound to the particulate fraction (the first pellet), (2) soluble enzyme (in the last supernatant), and (3) enzyme bound to glycogen particles (the second pellet). These fractions were assayed to determine the distribution of enzyme activity as well as the recovery of activity. Only data showing recoveries of $100 \pm 30 \%$ were retained.

Enzyme activity was measured using a UV/Vis spectrophotometer (Beckman/DU 640) to follow the absorbance of $\mathrm{NAD}(\mathrm{P}) \mathrm{H}$ at $340 \mathrm{~nm}$. The molar extinction coefficient for $\mathrm{NAD}(\mathrm{P}) \mathrm{H}$ was 6.22. All assays were run in duplicate and the specific activities were expressed in international units ( $\mu \mathrm{mol}$ of substrate converted to product $\left.\mathrm{min}^{-1}\right) \mathrm{U} \mathrm{g}^{-1}$ wet mass. Assay temperature was controlled at $6^{\circ} \mathrm{C}$ with a circulating refrigerating water bath (Haake D8). Enzymes were assayed using the following conditions (all concentrations in $\mathrm{mmol}^{-1}$ ).

Glycogen phosphorylase (EC 2.4.1.1): Imidazole$\mathrm{HCl} 50, \mathrm{KH}_{2} \mathrm{PO}_{4}$ 80, Mg-acetate 5, EDTA 2.5, $10 \mathrm{mg}$ $\mathrm{ml}^{-1}$ glycogen (omitted for the control), adenosine monophosphatel AMP 0.8, cyclic AMP 0.5, NADP 0.6, glucose-1,6-diphosphate 0.004 , excess glucose-6phosphate dehydrogenase and phosphoglucomutase, $\mathrm{pH} 7.5$.

Pyruvate kinase (EC 2.7.1.40): Imidazole- $\mathrm{HCl} 50$, $\mathrm{MgSO}_{4} 13, \mathrm{KCl} 100$, phosphoenolpyruvate 5 (omitted for the control), ADP 5, NADH 0.2, excess lactate dehydrogenase, $\mathrm{pH} 6.6$.

Octopine dehydrogenase: Imidazole-HCl 50, EDTA$\mathrm{Na}_{2} 2$, EGTA 5, KCN 1, sodium pyruvate 5 (omitted for the control), arginine-HCl 6, NADH 0.2, pH 6.6.

Chemicals. All biochemicals were from Boehringer Mannheim (Montreal, Canada) or Sigma Chemical (St. Louis, USA). All other chemicals were analytical grade.

Statistical analysis. Data were analyzed using a 1way ANOVA to test the null hypotheses of no differences between reproductive stages (Sokal \& Rohlf 1981). Sex differences at specific reproductive stages were examined with $t$-tests. Normality was tested using a Shapiro-Wilk's test (SAS 1999) and homogeneity of variances using a Levene test (Snedecor \& Cochran 1989). Least squares (LS) means multiple pairwise comparisons were used to test a posteriori for specific differences when the ANOVAs indicated significant $(p \leq 0.05)$ differences (SAS 1999).

\section{RESULTS}

\section{Muscle mass, protein and glycogen contents during reproductive cycle}

As we sampled scallops of the same size throughout the reproductive cycle, direct comparison of tissue masses was possible. In female and male Chlamys islandica, adductor-muscle wet mass (and dry mass in females) was stable during gonad maturation and spawning $(p>0.05)$. In male scallops, muscle dry mass decreased during gonad growth and began to recover 
after spawning $(p<0.05)$ (Table 1$)$. The mass of the adductor muscle did not differ between females and males $(p<0.05)$ before or after gonad maturation, except after spawning when the wet and dry masses of the adductor muscle were lower $(p<0.05)$ in males than in females. During gonad maturation and spawning in females, muscle protein levels ( $\mathrm{mg} \mathrm{g}^{-1}$ wet mass) remained constant. Similarly, during testis growth, adductor-muscle protein levels did not change; however, after spawning by males, adductor-muscle protein concentrations rose to their highest level, increasing by $12 \%(\mathrm{p}<0.05)$ (Fig. 1). The total protein content in the adductor muscle did not change during the reproductive cycle in females or males. In both female and male scallops, muscle glycogen dropped markedly (by 50 to $60 \%$ ) during gonad maturation and remained low after spawning $(\mathrm{p}<0.0001)$ (Fig. 1).

\section{Muscle-specific activities of glycolytic and mitochondrial enzymes}

Glycogen phosphorylase (GP) showed its highest activity in immature female and male scallops, declined with gonad maturation, and remained low after spawning (Table 2). In female scallops, octopine dehydrogenase (ODH) activity also decreased during gonad growth and remained low after spawning (Table 2). In males, the decrease and subsequent increase in ODH activities were not significant $(\mathrm{p}=$ 0.07). Pyruvate kinase (PK)-specific activities did not change with the reproductive cycle in females or males (Table 2). Thus the decrease in GP and ODH with maturation and spawning confirms our previous results even though the response of PK was weakened (Brokordt et al. 2000a). Since muscle protein concen-

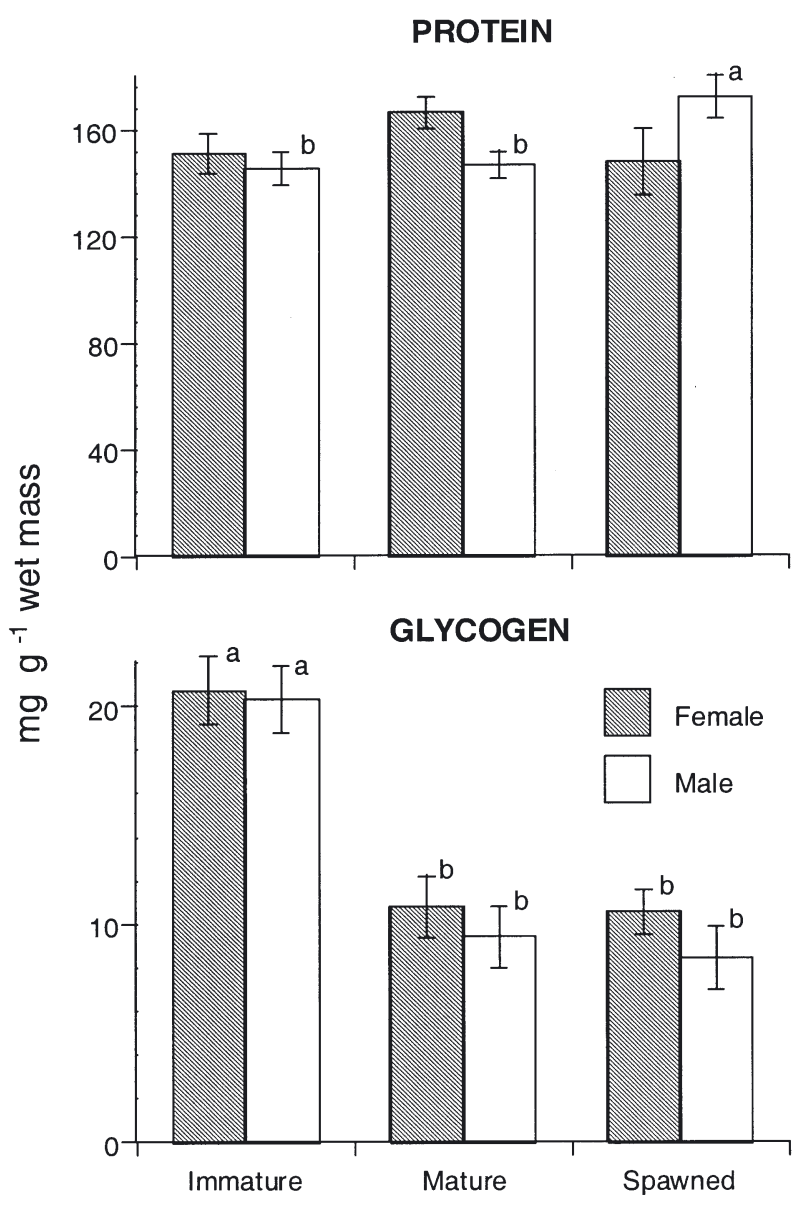

Fig. 1. Chlamys islandica. Changes in protein and glycogen concentrations ( $\mathrm{mg} \mathrm{g}^{-1}$ wet mass) in adductor muscle of female and male scallops sampled when gonads were immature, mature and spawned. For a given sex, means sharing the same letters were not significantly different $(p<0.05)$ as determined by LS means a posteriori multiple comparisons. Values without letters do not differ statistically
Table 1. Chlamys islandica. Mean $( \pm \mathrm{SE})$ wet and dry masses of the adductor muscle in female and male scallops, during different reproductive stages. Means sharing same letters were not significantly different as determined by least squares (LS) means a posteriori multiple comparisons. Where no letters are given for a series of values, these did not differ statistically

\begin{tabular}{|lccccr|}
\hline \multirow{2}{*}{$\begin{array}{l}\text { Reproductive } \\
\text { stage }\end{array}$} & \multicolumn{2}{c}{ Wet mass } & \multicolumn{2}{c|}{ Dry mass } & \multirow{2}{*}{$\mathrm{n}$} \\
\hline Fean & SE & Mean & SE & \\
Immature & 14.71 & 0.73 & 3.36 & 0.13 & 9 \\
Mature & 13.83 & 0.68 & 3.06 & 0.17 & 9 \\
Spawned & 14.47 & 0.91 & 3.28 & 0.21 & 10 \\
p-value & 0.694 & & 0.412 & & \\
Males & & & & & \\
Immature & 13.47 & 0.27 & $3.05^{\mathrm{a}}$ & 0.07 & 9 \\
Mature & 12.79 & 0.74 & $2.55^{\mathrm{b}}$ & 0.18 & 10 \\
Spawned & 12.16 & 0.45 & $2.79^{\mathrm{ab}}$ & 0.08 & 10 \\
p-value & 0.224 & & 0.023 & & \\
\hline
\end{tabular}

trations did not change in the same direction as enzyme activities, again the shifts in enzyme activity were not due to a general reduction in muscle protein.

\section{Separation of glycogen from particulate and soluble fractions}

The bulk of muscle glycogen (86 to $91 \%$ ) was consistently recovered in the glycogen pellet (Table 3). The soluble fraction contained no glycogen, and typically the first pellet (particulate fraction) contained only 6 to $9 \%$ of the total glycogen in the extract. The only exception to this pattern occurred in 
Table 2. Chlamys islandica. Enzyme activities ( $\mathrm{U} \mathrm{g}^{-1}$ wet mass) in adductor muscle of female and male scallops. Values are means \pm SE $(n=6$ to 10). GP: glycogen phosphorylase; ODH: octopine dehydrogenase; PK: pyruvate kinase. Further details as in legend to Table 1

\begin{tabular}{|lllcccc|}
\hline $\begin{array}{l}\text { Reproductive } \\
\text { stage }\end{array}$ & \multicolumn{2}{c}{ GP } & \multicolumn{2}{c}{ ODH } & \multicolumn{2}{c|}{ PK } \\
\hline Feanales & & SE & Mean & SE & Mean & SE \\
Immature & $0.994^{\mathrm{a}}$ & 0.103 & $20.15^{\mathrm{a}}$ & 1.30 & 14.09 & 1.08 \\
Mature & $0.605^{\mathrm{b}}$ & 0.045 & $14.94^{\mathrm{b}}$ & 1.17 & 13.57 & 0.95 \\
Spawned & $0.806^{\mathrm{b}}$ & 0.066 & $14.75^{\mathrm{b}}$ & 1.28 & 13.92 & 1.71 \\
p-value & 0.008 & & 0.009 & & 0.962 & \\
Males & & & & & & \\
Immature & $0.862^{\mathrm{a}}$ & 0.081 & 19.307 & 1.18 & 12.68 & 1.11 \\
Mature & $0.590^{\mathrm{b}}$ & 0.041 & 14.523 & 1.85 & 13.00 & 0.95 \\
Spawned & $0.785^{\mathrm{ab}}$ & 0.111 & 19.500 & 1.84 & 13.94 & 0.83 \\
p-value & 0.006 & & 0.067 & & 0.650 & \\
\hline
\end{tabular}

Table 3. Chlamys islandica. Mean $( \pm \mathrm{SE})$ percentage of glycogen isolated in final glycogen pellet and particulate fraction compared to glycogen in initial homogenate of adductor muscles from female and male scallops during different reproductive stages

\begin{tabular}{|lrrrrr|}
\hline $\begin{array}{l}\text { Reproductive } \\
\text { stage }\end{array}$ & \multicolumn{2}{c}{$\begin{array}{c}\text { Final glycogen } \\
\text { pellet } \\
\text { Mean }\end{array}$} & SE & Particulate fraction & $\mathrm{n}$ \\
& & & & & \\
\hline Females & 100.1 & 7.5 & 27.8 & 3.0 & 9 \\
Immature & 88.5 & 8.7 & 8.7 & 0.9 & 9 \\
Mature & 86.0 & 4.3 & 9.1 & 2.0 & 10 \\
Spawned & & & & & \\
Males & 84.6 & 11.4 & 6.0 & 0.6 & 9 \\
Immature & 91.1 & 6.3 & 8.9 & 1.6 & 10 \\
Mature & 90.3 & 10.3 & 6.0 & 6.0 & 10 \\
Spawned & & & & & \\
\hline
\end{tabular}

immature females, for which our measurements in the particulate and glycogen fractions over estimated the glycogen in the extract (in this case, the glycogen in the particulate fraction was $28 \%$ of the initial amount, and the glycogen fraction contained as much as the initial aliquot).

\section{Percent binding of enzyme activity}

The association of enzyme activity with subcellular fractions was considerable, particularly for GP (Table 4). GP showed the highest percent binding; with total binding between 50 and $72 \%$. GP binding to glycogen (9 to $19.5 \%$ ) was greater than that of $\mathrm{ODH}$ and $\mathrm{PK}$ ( 2 to $6.6 \%$ ). GP, ODH and PK activities expressed relative to glycogen in the final glycogen pellet did not change with reproductive status in females or males (Table 5).

Reproductive status affected the association of enzyme activity with the glycogen fraction (Table 4). The percent GP bound to the glycogen fraction decreased with gonad growth and spawning in both female and male scallops $(\mathrm{p}<0.05)$. In females, the percent binding of $\mathrm{ODH}$ to glycogen decreased

Table 4. Chlamys islandica. Mean percentage $( \pm$ SE) of enzyme activities associated with glycogen particles and total particulate fraction (including glycogen) of extracts of adductor muscle from female and male scallops during different reproductive stages. Further details as in legend to Table 1

\begin{tabular}{|c|c|c|c|c|c|c|c|c|c|c|}
\hline \multirow{3}{*}{$\begin{array}{l}\text { Reproductive } \\
\text { stage }\end{array}$} & \multicolumn{5}{|c|}{ Females } & \multicolumn{5}{|c|}{ Males $\longrightarrow$} \\
\hline & \multicolumn{2}{|c|}{ Bound to glycogen } & \multicolumn{2}{|c|}{ Total bound } & \multirow[t]{2}{*}{$\mathrm{n}$} & \multicolumn{2}{|c|}{ Bound to glycogen } & \multicolumn{2}{|c|}{ Total bound } & \multirow[t]{2}{*}{$\mathrm{n}$} \\
\hline & Mean & SE & Mean & SE & & Mean & SE & Mean & $\mathrm{SE}$ & \\
\hline \multicolumn{11}{|l|}{ GP } \\
\hline Immature & $19.47^{\mathrm{a}}$ & 2.29 & $71.48^{\mathrm{a}}$ & 3.78 & 8 & $17.96^{\mathrm{a}}$ & 2.50 & 65.79 & 3.22 & 9 \\
\hline Mature & $11.52^{\mathrm{b}}$ & 1.42 & $48.27^{b}$ & 6.36 & 7 & $9.22^{\mathrm{b}}$ & 1.20 & 62.12 & 2.42 & 8 \\
\hline Spawned & $13.25^{\mathrm{b}}$ & 2.31 & $66.81^{a}$ & 5.28 & 6 & 13.25 & 2.31 & 67.61 & 3.71 & 6 \\
\hline $\mathrm{p}$-value & 0.028 & & 0.006 & & & 0.009 & & 0.480 & & \\
\hline \multicolumn{11}{|l|}{ ODH } \\
\hline Immature & $2.79^{a}$ & 0.31 & $21.62^{\mathrm{a}}$ & 1.86 & 9 & $2.11^{\mathrm{b}}$ & 0.13 & $18.77^{a}$ & 0.73 & 10 \\
\hline Mature & $2.09^{b}$ & 0.06 & $15.04^{\mathrm{b}}$ & 1.03 & 8 & $2.27^{\mathrm{b}}$ & 0.26 & $14.67^{b}$ & 1.06 & 8 \\
\hline Spawned & $2.87^{\mathrm{a}}$ & 0.28 & $18.20^{\mathrm{a}}$ & 1.02 & 9 & $4.07^{a}$ & 0.44 & $15.53^{b}$ & 1.53 & 7 \\
\hline p-value & 0.050 & & 0.007 & & & 0.0001 & & 0.038 & & \\
\hline \multicolumn{11}{|l|}{ PK } \\
\hline Immature & 3.12 & 0.28 & 16.37 & 1.58 & 9 & 2.98 & 0.20 & 17.39 & 1.44 & 9 \\
\hline Mature & 2.63 & 0.20 & 17.96 & 1.63 & 8 & 2.47 & 0.31 & 18.36 & 0.99 & 10 \\
\hline Spawned & 2.47 & 0.23 & 16.09 & 1.14 & 9 & 2.90 & 0.42 & 19.00 & 1.92 & 9 \\
\hline p-value & 0.155 & & 0.643 & & & 0.475 & & 0.741 & & \\
\hline
\end{tabular}


Table 5. Chlamys islandica. Enzyme activities expressed relative to glycogen in the final glycogen pellet ( $\mathrm{U} \mathrm{mg}^{-1}$ glycogen) in adductor muscle of female and male scallops, during different reproductive stages. Values are means \pm SE ( $n=6$ to 10)

\begin{tabular}{|lcccccc|}
\hline $\begin{array}{l}\text { Reproductive } \\
\text { stage }\end{array}$ & \multicolumn{2}{c}{ GP } & \multicolumn{2}{c}{ ODH } & \multicolumn{2}{c|}{ PK } \\
& Mean & SE & Mean & SE & Mean & SE \\
\hline $\begin{array}{l}\text { Females } \\
\text { Immature }\end{array}$ & 0.086 & 0.016 & 0.320 & 0.069 & 0.311 & 0.072 \\
Mature & 0.056 & 0.010 & 0.290 & 0.073 & 0.343 & 0.076 \\
Spawned & 0.076 & 0.018 & 0.295 & 0.064 & 0.238 & 0.062 \\
p-value & 0.172 & & 0.949 & & 0.589 & \\
Males & & & & & & \\
Immature & 0.095 & 0.016 & 0.262 & 0.073 & 0.219 & 0.055 \\
Mature & 0.069 & 0.010 & 0.372 & 0.065 & 0.352 & 0.043 \\
Spawned & 0.066 & 0.019 & 0.418 & 0.071 & 0.385 & 0.058 \\
p-value & 0.308 & & 0.127 & & 0.101 & \\
\hline
\end{tabular}

with maturation but increased with spawning ( $\mathrm{p}<$ 0.05). In males, the percent binding of ODH to glycogen increased with spawning. The association of PK with the glycogen fraction did not change with reproductive status in females or males.

Changes in reproductive status also modified the overall association of enzymes with subcellular fractions. The total binding of GP (total percent bound to glycogen and particulate fractions) decreased with gonad growth and increased with spawning in females. Total binding of GP did not change in males. In females and males, the total percent binding of $\mathrm{ODH}$ decreased with gonad growth. After spawning, total $\mathrm{ODH}$ binding increased in females whereas it remained low in males. During the reproductive cycle, total percent binding did not change for PK. Throughout the reproductive cycle, in both females and males, the total percent binding of GP was about 3-fold that of $\mathrm{ODH}$ and PK.

\section{Enzyme activity (units) associated with glycogen, particulate and soluble fractions}

For both female and male scallops, more GP (U in glycogen fraction $\mathrm{g}^{-1}$ muscle) (Fig. 2) was bound to glycogen in immature than in mature or spawned individuals ( $\mathrm{p}=0.0002$ ). As the $\mathrm{U} \mathrm{mg}^{-1}$ glycogen did not change, the change in PG units in the glycogen fraction reflected the higher levels of glycogen in immature scallops. This relationship supports the hypothesis that binding to glycogen influences GP activity. In females, the activity of GP bound to the particulate fraction was greater in immature than in mature or spawned individuals $(p=0.0008$ ) and GP activity in the soluble fraction did not differ with reproductive state $(p=0.42)$. In male scallops, reproductive state did not significantly influence GP activ- ity in the particulate and soluble fractions ( $p=0.15$ and 0.054 , respectively).

In female scallops, reproductive state influenced the activity of ODH in the glycogen, particulate and soluble fractions $(\mathrm{p}=0.011,0.001$ and 0.046, respectively) (Fig. 2). ODH activity in each fraction was highest in immature females and decreased with maturation, but the changes were greatest in the glycogen and particulate fractions. In males, although reproductive state did not influence $\mathrm{ODH}$ activity in the soluble or particulate fractions, spawning increased the ODH activity associated with glycogen. The association of PK with the different fractions did not change with reproductive status in female or male scallops.

\section{Relative levels of enzymes in subcellular fractions}

Whereas the range of total specific activities of the 4 enzymes was considerable (Table 2), the activities associated with the glycogen and particulate fractions were more similar. For a given reproductive state, the activities $\left(\mathrm{U} \mathrm{g}^{-1}\right)$ of $\mathrm{GP}, \mathrm{ODH}$, and PK associated with the glycogen particles varied approximately 4 -fold, and those associated with the particulate fraction varied about 5-fold (Fig. 2). On the other hand, the activities in the soluble fraction ranged from approximately 0.2 to $15 \mathrm{U} \mathrm{g}^{-1}$ (Fig. 2). These relationships reflect the fact that the enzyme with the lowest specific activity (GP) had the greatest binding (Table 4). Even though the association of ODH and PK with the glycogen fraction was limited, the resulting capacities were similar to that of GP in this fraction. A similar pattern was observed in the particulate fraction.

When the activities of ODH and PK in the glycogen and particulate fractions were expressed relative to GP activity (ODH/GP or PK/GP), the 2 ratios were similar in each reproductive state (Table 6). In the glycogen fraction, these ratios differed between reproductive states, but little between sexes. Thus, both ratios ranged between 2.4 and 2.7 in immature scallops, while mature scallops had ratios between 4.7 and 5.2 (Table 6). Spawned scallops had more variable ratios, with females showing lower ratios than males. The impact of reproductive status on these ratios was significant $(p<0.05)$ except for PK/GP in males $(p=0.22)$. In the particulate fraction, again the ratios of ODH/GP and PK/GP tended to differ with reproductive state, but were similar between sexes. These ratios suggest conservation of a stoi- 
chiometry between the glycolytic enzymes associated with subcellular fractions, but indicate that this stoichiometry varies with reproductive state.
FEMALES

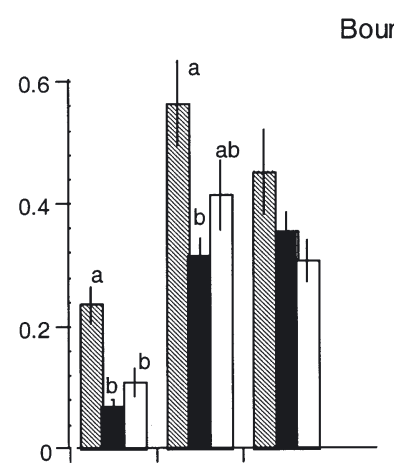

MALES

Bound to Glycogen Fraction

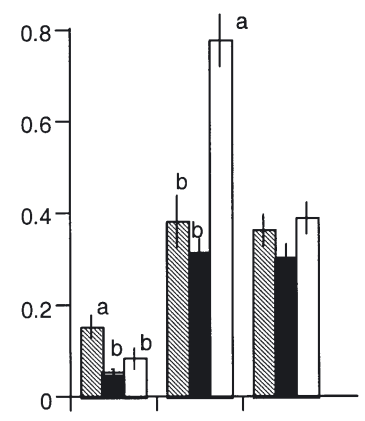

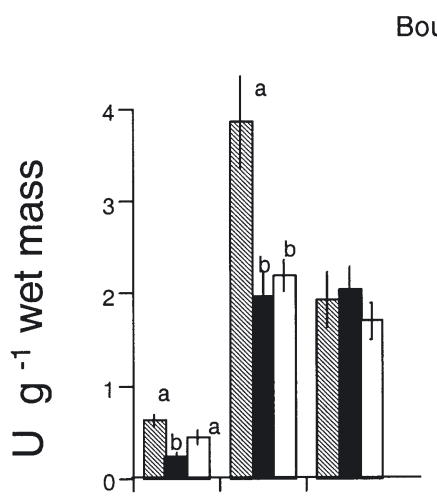

Bound to Particulate Fraction
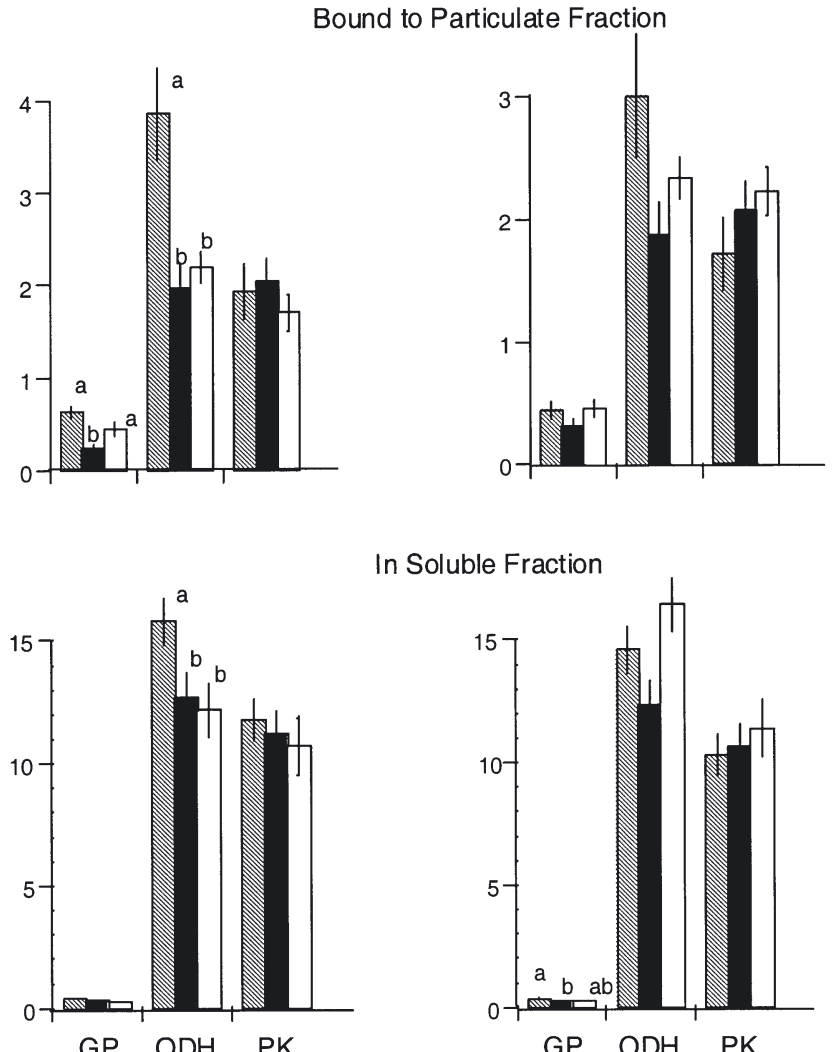

In Soluble Fraction

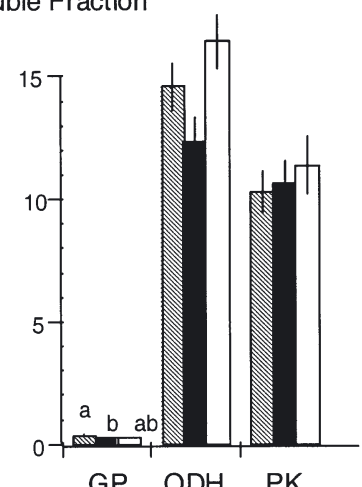

Immature

Mature

Spawned

Fig. 2. Chlamys islandica. Impact of reproductive status upon association of activities ( $\mathrm{U} \mathrm{g}^{-1}$ wet mass) of glycogen phosphorylase (GP), octopine dehydrogenase (ODH) and pyruvate kinase (PK) with glycogen, particulate and soluble fractions of adductor muscles in female and male scallops. For a given enzyme in a given fraction, means sharing same letters were not significantly different $(\mathrm{p}<0.05)$ as determined by LS means $a$ posteriori multiple comparisons. Values without letters do not differ statistically

\section{DISCUSSION}

As observed in many scallop species, marked mobilization of muscle glycogen occurred during gonad growth and spawning of the Iceland scallop Chlamys islandica. Initial glycogen levels were depleted by 50 to $60 \%$ in the adductor muscle of female and male scallops. Soluble proteins are twice as abundant as glycogen in this muscle (Brokordt et al. 2000a), but protein concentrations change little during the reproductive cycle. Nonetheless, the specific activities of glycogen phosphorylase (GP) and octopine dehydrogenase $(\mathrm{ODH})$ decreased with gonad maturation and spawning, particularly in females. Our hypothesis that the decreased activity of glycolytic enzymes was due to the mobilization of glycogen and a loss of binding sites for these enzymes was partly confirmed. As the binding of GP per mg glycogen did not change with reproductive status, the reduction of glycogen levels led the percent of GP bound to glycogen to decrease with gonad growth and spawning in females and males. This decrease paralleled the reduction in GP-specific activity. The ratios of ODH/GP and pyruvate kinase (PK)/GP in the glycogen fraction were surprisingly constant, particularly in immature and mature scallops, suggesting maintenance of a constant stoichiometry in the glycolytic pathway. On the other hand, maximally $20 \%$ of GP activity was bound to the glycogen fraction under our experimental conditions. Further, a considerably lower percentage of ODH and PK activity was bound to glycogen, suggesting that the dynamics of their specific activities were not directly dictated by the availability of binding sites on glycogen. Our experimental conditions allowed us to isolate virtually all the glycogen in the adductor muscle, but the low ionic strength of the extraction buffer (Birkel et al. 1986) may have changed enzyme-binding to glycogen particles. Nonetheless, a high proportion of enzyme activity was associated with the particulate fraction, presumably largely composed of myofibrillar and other structural proteins.

The binding of glycolytic enzymes to the particulate fraction of scallop adductor muscle changed with reproductive status, particularly in females. For GP and $\mathrm{ODH}$, the units bound decreased with gonad maturation and spawning. Whereas short-term stress such as ischemia, anoxia or exercise changes enzymebinding to the particulate fraction in muscle for limpets, whelks, frogs, rats and sheep (Clarke et al. 1984, Lowery et al. 1987, Roberts \& Somero 1987, Brooks \& Storey 1988, 1990, 1991, Guderley et al. 1989, Lazou et al. 1989, Huber \& Guderley 1993), our study is one of the few to demonstrate that enzymebinding to the particulate fraction of muscle changes with long-term physiological change, such as that 
Table 6. Chlamys islandica. Ratios (means $\pm \mathrm{SE}, \mathrm{n}=6$ to 10) of ODH/GP and PK/GP in the adductor muscle of female and male scallops, at different reproductive stages. Further details as in legend to Table 1

\begin{tabular}{|c|c|c|c|c|c|c|c|c|}
\hline \multirow{3}{*}{$\begin{array}{l}\text { Reproductive } \\
\text { stage }\end{array}$} & \multicolumn{4}{|c|}{ Bound to glycogen } & \multicolumn{4}{|c|}{ Bound to particulate fraction } \\
\hline & \multicolumn{2}{|c|}{ ODH/GP } & \multicolumn{2}{|c|}{ PK/GP } & \multicolumn{2}{|c|}{ ODH/GP } & \multicolumn{2}{|c|}{ PK/GP } \\
\hline & Mean & $\mathrm{SE}$ & Mean & SE & Mean & SE & Mean & $\mathrm{SE}$ \\
\hline \multicolumn{9}{|l|}{ Females } \\
\hline Immature & $2.42^{\mathrm{b}}$ & 0.37 & $2.49^{b}$ & 0.42 & 6.11 & 0.87 & $3.91^{b}$ & 1.13 \\
\hline Mature & $5.04^{\mathrm{a}}$ & 0.79 & $5.16^{\mathrm{a}}$ & 0.56 & 9.19 & 2.00 & $9.55^{\mathrm{a}}$ & 1.53 \\
\hline Spawned & $4.35^{\mathrm{a}}$ & 0.39 & $3.29^{b}$ & 0.63 & 4.08 & 0.15 & $4.55^{\mathrm{b}}$ & 1.25 \\
\hline p-value & 0.017 & & 0.007 & & 0.092 & & 0.013 & \\
\hline \multicolumn{9}{|l|}{ Males } \\
\hline Immature & $2.70^{\mathrm{c}}$ & 0.61 & 2.63 & 0.55 & 6.64 & 0.83 & 4.25 & 0.89 \\
\hline Mature & $4.70^{\mathrm{b}}$ & 0.45 & 4.98 & 0.79 & 6.40 & 1.08 & 6.45 & 0.31 \\
\hline Spawned & $7.28^{\mathrm{a}}$ & 1.14 & 4.55 & 1.37 & 5.23 & 2.25 & 5.11 & 0.80 \\
\hline p-value & 0.003 & & 0.216 & & 0.741 & & 0.071 & \\
\hline
\end{tabular}

which occurs during reproduction. As the scallops we sampled were maintained without disturbance before sampling, the levels of enzyme-binding are of unstressed individuals. Changes in enzyme-binding may play a role in short-term metabolic regulation, although this interpretation remains controversial (Brooks \& Storey 1991, Hochachka \& Somero 2002). Our results point to a role of enzyme localization in setting rates of enzyme synthesis and degradation. Decreases in enzyme-binding to the particulate fraction generally paralleled reductions of enzymespecific activity. The most marked shifts in binding occurred for GP and ODH: their changes in activity were also the most pronounced. Decreased binding to subcellular fractions may render metabolic enzymes more susceptible to degradation, leading their catalytic activities to drop considerably even though total protein concentrations remained stable. An analogous result is seen during warm acclimation of white sucker Catastomus commersoni, in which the mitochondrial localization of the citrate synthase was suggested to prevent its protection by the heat shock protein (HSP) 70, thereby accelerating its degradation and the reduction in activity (Hardewig et al. 2000).

Suggestive of a functional role for binding of enzymes to subcellular particles, the activities of the 3 enzymes in the glycogen and particulate fractions lay in a much narrower range than their activities in the soluble fraction. Similarly, the relative levels of glycolytic enzymes bound to subcellular particles changed little with exercise in trout white muscle, even though the percent binding of these enzymes changed considerably (Brooks \& Storey 1988). For scallops of a given reproductive state, the ratios of ODH/GP and PK/GP bound to the glycogen and particulate fractions remained quite constant. This similarity was particularly striking in the glycogen fraction. While the activity ratios differed little between sexes, they differed considerably between reproductive states, with higher ODH/GP and PK/GP characterizing muscles of mature and spawned scallops. This pattern was less pronounced in the particulate fraction.

A physical link between the glycogen particles and the enzymes of glycogen metabolism would seem a prerequisite for the breakdown and synthesis of this macromolecular reserve. However, the binding of metabolic enzymes to glycogen has received little attention in non-mammalian species. In mammalian muscle, the enzymes of glycogen metabolism, phosphorylase, glycogen synthase and their regulatory enzymes as well as phosphofructokinase show significant binding to glycogen particles (Birkel et al. 1986). Lactate dehydrogenase shows little binding to glycogen in mammalian muscle. In rabbit psoas muscle, the binding of total GP $(\mathrm{a}+\mathrm{b})$ to glycogen particles rises from 21 to $28 \%$ with starvation, while that of activated GP (a) decreases (Birkel et al. 1986). In adductor muscle from immature scallops, total GP activity was bound to glycogen to a similar extent as in psoas muscle from fed rabbits. Although only a small proportion of ODH activity was bound to glycogen in scallop muscle, this was equivalent to between 2 and 9 times the GP activity. Scallop muscle contains glycogen concentrations typical of or higher than those in mammalian glycolytic fibers (Adamo \& Graham 1998, Brokordt et al. 2000a,b). As the marked changes in glycogen levels in the scallop adductor muscle with gonad maturation and spawning seem to have changed the intracellular localization of GP and $\mathrm{ODH}$, by analogy similar changes may occur with mobilization of muscle reserves in other organisms.

Our comparison of female and male scallops was based on the premise that sex differences in reproductive investment could lead to different extents of glyco- 
gen mobilization from the adductor muscle during maturation and spawning. These in turn could have modified the dynamics of glycolytic enzyme-binding to glycogen. However, we found no marked differences in the decreases of muscle glycogen with maturation and spawning of females and males. The responses of enzyme activities and enzyme-binding differed slightly between female and male scallops, with certain responses being more pronounced in females. However, the overall patterns of enzyme-binding were similar between female and male scallops.

Acknowledgements. Many thanks to M. Guay for his reliable and careful sampling and care of the scallops and to J. H. Himmelman for the use of his laboratory at Havre St. Pierre. This study was supported by a grant from NSERC to H.G.

\section{LITERATURE CITED}

Adamo KB, Graham TW (1998) Comparison of traditional measurements with macroglycogen and proglycogen analysis of muscle glycogen. J Appl Physiol 84:980-913

Barber BJ, Blake NJ (1991) Reproductive physiology. In: Shumway SE (ed) Scallops: biology, ecology and aquaculture. Developments in Aquaculture and Fisheries Science, Vol 21. Elsevier Science, New York, p 377-428

Birkel G, Bauer HP, Hofer HW (1986) Phosphofructokinase activity and the binding of enzymes to glycogen particles in the perfused psoas muscle of the rabbit. Int $\mathrm{J}$ Biochem 18:79-83

Brokordt KB, Guderley HE (in press) Energetic requirements during gonad maturation and spawning in scallops: sex differences in Chlamys islandica (Müller 1976). J Shellfish Res

Brokordt KB, Himmelman JH, Guderley HE (2000a) Effect of reproduction on escape responses and muscle metabolic capacities in the scallop Chlamys islandica Müller 1776. J Exp Mar Biol Ecol 251:205-225

Brokordt KB, Himmelman JH, Nusetti OA, Guderley HE (2000b) Reproductive investment reduces recuperation from escape responses in the tropical scallop Euvola ziczac. Mar Biol 137:857-865

Brooks S, Storey KB (1988) Subcellular enzyme binding in glycolytic control: in vivo studies with fish muscle. Am J Physiol 255: R289-R294

Brooks S, Storey KB (1990) Glycolytic enzyme binding and metabolic control in estivation and anoxia in the land snail

Editorial responsibility: John Lawrence (Contributing Editor), Tampa, Florida, USA
Otala lactea. J Exp Biol 151:193-204

Brooks S, Storey KB (1991) Studies on the regulation of enzyme binding during anoxia in isolated tissues of Busycon canaliculatum. J Exp Biol 156:467-481

Choate GL, Lan L, Mansour TE (1985) Heart 6-phosphofructose-1-kinase: subcellular distribution and binding to myofibrils. J Biol Chem 260:4815-4822

Clarke FM, Stephan P, Huxham G, Hamilton D, Morton DJ (1984) Metabolic dependence of glycolytic enzyme binding in rat and sheep heart. Eur J Biochem 138:643-649

Gagnon R, Lehoux EA, Guderley HE (1998) Manually operated freeze clamping press. Anal Biochem 260:251-252

Guderley H, Jean C, Blouin M (1989) The effect of fatigue on the binding of glycolytic enzymes in the isolated gastrocnemius of Rana pipiens. Biochem Biophys Acta 977: $87-90$

Hardewig I, Van Dijk PLM, Leary SC, Moyes CD (2000) Temporal changes in enzyme activity and mRNA levels during thermal challenge in white sucker. J Fish Biol 56:196-207

Hochachka PW, Somero GN (2002) Biochemical adaptation: mechanism and process in physiological evolution. Oxford University Press, New York

Huber M, Guderley H (1993) The effect of thermal acclimation and exercise upon the binding of glycolytic enzymes in muscle of the goldfish Carassius auratus. J Exp Biol 175: 195-209

Keppler D, Decker K (1974) Glycogen determination with amyloglucosidase. In: Bergmeyer HU (ed) Methods of enzymatic analysis. Verlag Chemie, Weinheim, p 1127-1131

Lazou A, Michaelidis B, Beis I (1989) Evidence for glycolytic enzyme binding during anaerobiosis of the foot muscle of Patella caerulea (L.). J Comp Physiol B 158:771-777

Lowery MS, Roberts SJ, Somero GN (1987) Effects of starvation on the activities and localization of glycolytic enzymes in the white muscle of the barred sand bass Paralabrax nebulifer. Physiol Zool 60:538-549

Roberts SJ, Somero GN (1987) Binding of phosphofructokinase to filamentous actin. Biochemistry 26:3437-3442

SAS (1999) SAS/STAT user's guide release 8.02 edn. SAS Institute Press, Cary, NC

Smith PK, Krohn RI, Hermanson GT, Matha AK and 6 others (1985) Measurements of protein using bicinchoninic acid. Anal Biochem 150:76-85

Snedecor GW, Cochran WG (1989) Statistical methods, 8th edn. Iowa State University Press, Ames

Sokal RR, Rohlf FJ (1981) Biometry: the principles and practice of statistics in biological research, 2nd edn. WH Freeman, New York

Srere PA (1987) Complexes of sequential metabolic enzymes. Annu Rev Biochem 56:1-68

Submitted: June 17, 2003; Accepted: November 24, 2003

Proofs received from author(s): February 23, 2004 